Volume 02 Nomor 01, Juni 2020 Page 1-8

Incrementapedia: Jurnal Pendidikan Anak Usia Dini

Program Studi PG-PAUD Fakultas Pedagogik dan Psikologi

Universitas PGRI Adi Buana Surabaya

http://jurnal.unipasby.ac.id/index.php/incrementapedia

e-ISSN: 2686-3146

\title{
Penerapan Metode Eksperimen untuk Meningkatkan Keterampilan Proses Sains Anak Usia Dini
}

\author{
Luluk Iffatur Rocmah, Nur Hidayatus Sholihah \\ Program Studi Pendidikan Guru Pendidikan Anak Usia Dini \\ Fakultas Psikologi dan Ilmu Pendidikan \\ Universitas Muhammadiyah Sidoarjo \\ luluk.iffatur@umsida.ac.id
}

\begin{abstract}
This research is a classroom action research that aims to improve science process skills in early childhood. Science process skills are children's abilities in thinking and investigating the natural environment around a series of learning processes. These skills are abilities that use reason, reason and effective and efficient actions to achieve certain results. With science process skills children can find facts that occur in their environment. Science process skills in group B children in PAUD Tashwirul Afkar are still low, therefore experimental methods are applied in the learning process to improve the condition. The results of applying experimental methods with natural materials can improve the science process skills of group B children in PAUD Tashwirul Afkar. This is indicated by an increase in the percentage of children's science process skills since the action was taken at the pre-cycle, cycle I and cycle II. At the pre-cycle completeness the overall value of the child is $33 \%$. In the first cycle the overall value of the child is $58 \%$ and in the second cycle the overall value of the child is $91 \%$.
\end{abstract}

Keywords: Science Process Skills, Experimental Methods

\section{PENDAHULUAN}

Pendidikan anak usia dini merupakan salah satu program pendidikan yang terstruktur untuk mewujudkan suasana belajar yang menyenangkan, sehingga menciptakan proses pembelajaran yang mampu mengembangkan kemampuan peserta didiknya untuk memiliki kekuatan spiritual, kepribadian, kercerdasan dan akhlak mulia, serta keterampilan yang diperlukan oleh dirinya, masyarakat, bangsa dan negara. Proses belajar akan lebih maksimal jika dilakukan sejak anak usia dini. Hal ini disebabkan karena masa anak usia dini adalah masa emas (the golden age), yang mana dalam masa ini pertumbuhan dan semua aspek perkembangan anak berkembang sangat pesat.

Dari seluruh aspek yang ada, aspek perkembangan kognitif adalah aspek yang paling utama dalam mempengaruhi aspek perkembangan lainnya. Banyak kemampuan anak yang masuk kedalam perkembangan kognitif yang harus dikembangkan oleh pendidik, mulai dari konsep bilangan, lambang bilangan, warna, ukuran, bentuk dan sains. Dalam bidang sains, kompetensi yang harus dimiliki adalah anak mampu mengenal dan bereksplorasi terhadap benda-benda yang ada di sekitar baik itu benda mati ataupun hidup sehingga anak terampil dalam pelaksaan proses pembelajaran sains yang ingin dipelajari. 
Menurut James Conant (dalam Nugraha, 2015:3) sains adalah suatu konsep yang berhubungan satu sama lain yang berkembang sebagai hasil dari beberapa percobaan dan pengamatan serta dapat diuji coba dan diamati lebih lanjut. Pengenalan tentang ilmu Sains sebaiknya dilakukan pada saat anak usia dini dengan kegiatan yang menyenangkan dan eksploratif agar anak mengetahui proses sains yang telah dilakukannya, jadi anak bisa mengetahui sebab dan akibat terjadinya suatu percobaan yang telah dia lakukan, karena di keterampilan proses sains ini lebih mengedepankan proses daripada produk.

Menurut Widiyanti (2016) Keterampilan proses sains adalah kecakapan anak dalam berfikir dan menyelediki lingkungan alam sekitar ke dalam rangkaian proses pembelajaran.

Keterampilan tersebut merupakan kemampuan yang menggunakan akal fikiran, nalar serta tindakan yang efektif dan efisien untuk mencapai hasil tertentu. Dengan keterampilan proses sains anak dapat menemukan fakta yang terjadi di lingkungannya. Keterampilan proses sains yang diajarkan kepada anak lebih diutamakan dalam keterampilan berfikir sehingga anak bisa membangun pengetahuannya sendiri.

Keterampilan-keterampilan yang cocok dikembangkan pada anak usia pra sekolah adalah keterampilan mengamati, menggolongkan, mengukur, menjelaskan, mengajukan pertanyaan, dan mengklasifikasi hasil pembelajaran yang didapat (Samatowa, 2018:92). Pendekatan pembelajaran proses sains seharusnya dilakukan dengan menyenangkan agar memunculkan motivasi instrinsik dalam diri anak untuk menjawab rasa ingin tahu dengan menyajikan bahan-bahan yang ada disekitar sehingga terbentuk pengetahuan yang bermakna bagi anak.

Kurangnya keterampilan proses sains pada anak usia dini dikarenakan pembelajaran sains lebih banyak menggunakan kegiatan mewarnai dan menulis di lembar kerja anak. Sering dilakukan dalam keterampilan proses sains anak hanya sekedar menonton dan guru yang melakukan percobaan karena keterbatasan media pembelajaran yang kurang memadai. Keterampilan proses sains anak terhambat karena anak tidak mempunyai kesempatan untuk bereksplorasi langsung dengan alam sekitar.

Berdasarkan hasil pengamatan yang telah dilakukan di TK B PAUD Tashwirul Afkar data yang diperoleh dari hasil observasi yang diteliti, bahwa keterampilan sains dari 13 anak yang diobservasi terdapat 4 anak yang tergolong kreteria cukup karena mereka memiliki rasa ingin tahu yang tinggi. Dalam proses pembelajaran sains 4 anak ini sangat aktif mengajukan beberapa pertanyaan dan mampu menjawab pertanyaan sederhana (apa, bagaimana) yang diberikan oleh guru setelah pembelajaran proses sains berlangsung. Dan 9 anak yang lainnya tergolong kriteria kurang sekali, dikarenakan anak masih ragu- ragu untuk mencoba hal yang baru karena pembelajaran sains yang dilakukan di sekolah ini hanya memberi kesempatan pada anak melihat percobaan yang didemonstrasikan oleh guru (anak sebagai pengamat). Maka dengan penelitian ini anak mampu menghubungkan sebab dan akibat dari suatu percobaan sehingga melatih anak berfikir logis, anak dapat bereksplorasi terhadap berbagai benda yang ada disekitarnya, dan dalam sains ini anak juga dapat mengonstruksi pengetahuan berdasarkan 
apa yang telah dilihatnya dan yang telah dipraktekkan.

Setelah melakukan pengamatan lebih rinci peneliti menemukan penyebab terjadinya yakni guru lebih mengedepankan anak untuk mengerjakan lembar kerja sehingga kurang menarik minat anak. Sehingga pembelajaran sains yang disampaikan kurang maksimal, karena aktivitas pembelajaran yang terpusat oleh guru, membosankan dan sulit dipahami karena anak tidak mengalami proses secara langsung.

Melihat permasalahan yang terjadi di kelas, peneliti memilih metode eksperimen sebagai obat untuk menangani permasalahan yang ada di kelas. Metode eksperimen adalah metode yang memberikan kesempatan anak untuk aktif melakukan percobaan sendiri dengan cara mengamati proses dan hasil percobaan yang telah dilakukan. Dengan metode ini pula anak dapat mengembangkan kemampuan kognitif, afektif, dan psikomotor (Suyanto, 2014:77).

Mengingat pentingnya masalah ini untuk diatasi dan beberapa uraian mengenai metode eksperimen diatas, maka peneliti memilih menggunakan metode eksperimen berbahan alam untuk meningkatkan keterampilan proses sains pada kelompok B. Dengan metode eksperimen berbahan alam anak dapat menjelaskan tentang proses terjadinya sesuatu dengan menerapkan prinsip learning by experience (belajar dari pengalaman). Sehingga dari percobaan diatas anak mengetahui proses terjadinya sesuatu, anak dapat bereksplorasi terhadap benda hidup maupun benda mati, anak dapat menggunakan panca inderanya untuk mengenal berbagai benda dan peristiwa.

\section{METODE PENELITIAN}

Penelitian ini merupakan penelitian tindakan kelas, dengan tujuan untuk memecahkan permasalahan yang ada di kelas dan memperbaiki kualitas pembelajaran. Menurut Amir (2017:7) Penelitian Tindakan Kelas merupakan refleksi yang dilakukan oleh para partisipan (guru, siswa, dan kepala sekolah) dalam situasi pendidikan untuk memperbaiki dan meningkatkan kualitas praktek pendidikan itu sendiri.

Model yang digunakan dalam penelitian tindakan kelas ini menggunakan model yang diungkapkan oleh Kemmis dan Mc.Taggart yang merupakan pengembangan dari model Kurt Lewin. Model ini mencakup beberapa konsep yaitu: 1. Planning atau Perencanaan, 2. Acting atau Pelaksanaan, 3. Observing atau Observasi, 4. Reflecting atau Refleksi (Arikunto, 2010:108).

Penelitian tindakan kelas ini menggunakan bentuk kolaboratif yaitu peneliti bersama seorang guru kelas bekerja sama dalam pelaksanaan penelitian dan mengatasi masalah-masalah pembelajaran. Kehadiran peneliti dalam penelitian ini yaitu sebagai pengamat, perencana, pelaksana, pengumpul data, dan perancang tindakan. Menurut Kusumah (2017:20) Peneliti dalam penelitian tindakan kelas juga mengemban sebagai penanggung jawab penuh dalam penelitian.

Penelitian ini dilakukan di PAUD Tashwirul Afkar Gedangan Sidoarjo. Sedangkan yang menjadi sumber data penelitian peningkatan keterampilan proses sains melalui metode eksperimen berbahan alam berasal dari anak-anak kelompok B yang berjumlah 13 anak, kepala sekolah dan guru kelas. 
Penelitian ini menggunakan tiga macam teknik pengumpulan data yaitu, observasi, dokumentasi dan wawancara. Sedangkan instrumen yang digunakan adalah lembar RKH (Rencana Kegiatan Harian) dan lembar penilaian keterampilan proses sains anak kelompok B melalui metode eksperimen berbahan alam. Adapun kriteria penilaian keterampilan proses sains anak sebagai berikut:

Tabel 1. Kriteria penilaian keterampilan proses sains

\begin{tabular}{|c|c|c|c|}
\hline No & Indikator & Indikator Pencapaian & Skor \\
\hline \multirow{4}{*}{1.} & \multirow{4}{*}{$\begin{array}{l}\text { Anak mampu } \\
\text { melakukan } \\
\text { eksplorasi } \\
\text { terhadap } \\
\text { berbagai benda }\end{array}$} & $\begin{array}{l}\text { Anak mampu } \\
\text { melakukan eksplorasi } \\
\text { dan berinteraksi } \\
\text { langsung dengan alam. }\end{array}$ & 4 \\
\hline & & $\begin{array}{l}\text { Anak mampu } \\
\text { melakukan eksplorasi } \\
\text { dan berinteraksi } \\
\text { langsung dengan alam } \\
\text { tetapi hasilnya belum } \\
\text { maksimal. }\end{array}$ & 3 \\
\hline & & $\begin{array}{l}\text { Anak mampu } \\
\text { melakukan eksplorasi } \\
\text { dan berinteraksi } \\
\text { langsung dengan alam } \\
\text { dengan bantuan } \\
\text { guru/teman. }\end{array}$ & 2 \\
\hline & & $\begin{array}{l}\text { Anak belum mampu } \\
\text { melakukan eksplorasi } \\
\text { (ragu-ragu) }\end{array}$ & 1 \\
\hline \multirow{4}{*}{2.} & \multirow{4}{*}{$\begin{array}{l}\text { Anak mampu } \\
\text { mengkonstruksi } \\
\text { pengetahuannya } \\
\text { sendiri }\end{array}$} & $\begin{array}{l}\text { Anak aktif bertanya saat } \\
\text { proses pembelajaran } \\
\text { berlangsung }\end{array}$ & 4 \\
\hline & & $\begin{array}{l}\text { Anak bertanya saat } \\
\text { proses pembelajaran } \\
\text { berlangsung }\end{array}$ & 3 \\
\hline & & $\begin{array}{l}\text { Anak mampu bertanya } \\
\text { pada saat proses } \\
\text { pembelajaran } \\
\text { berlangsung dengan } \\
\text { motivasi yang diberikan } \\
\text { oleh guru. }\end{array}$ & 2 \\
\hline & & $\begin{array}{l}\text { Anak diam saja saat } \\
\text { proses pembelajaran } \\
\text { berlangsung. }\end{array}$ & 1 \\
\hline \multirow[t]{2}{*}{3.} & \multirow[t]{2}{*}{$\begin{array}{l}\text { Anak mampu } \\
\text { menjawab } \\
\text { pertanyaan apa } \\
\text { dan bagaimana }\end{array}$} & $\begin{array}{l}\text { Anak mampu menjawab } \\
\text { pertanyaan sederhana } \\
\text { secara rinci terkait } \\
\text { percobaan yang telah } \\
\text { dilakukan }\end{array}$ & 4 \\
\hline & & $\begin{array}{l}\text { Anak mampu menjawab } \\
\text { pertanyaan sederhana }\end{array}$ & 3 \\
\hline
\end{tabular}

\begin{tabular}{|c|c|c|c|}
\hline No & Indikator & Indikator Pencapaian & Skor \\
\hline & & $\begin{array}{l}\text { terkait percobaan yang } \\
\text { telah dilakukan }\end{array}$ & \\
\hline & & $\begin{array}{l}\text { Anak mampu menjawab } \\
\text { pertanyaan sederhana } \\
\text { terkait percobaan yang } \\
\text { telah dilakukan dengan } \\
\text { motivasi dan bantuan } \\
\text { guru. }\end{array}$ & 2 \\
\hline & & $\begin{array}{l}\text { Anak belum mampu } \\
\text { menjawab pertanyaan } \\
\text { sederhana terkait } \\
\text { percobaan yang telah } \\
\text { dilakukan }\end{array}$ & 1 \\
\hline
\end{tabular}

Teknik analisis data penelitian tindakan kelas ini merupakan data kualitatif dan kuantitatif. Deskriptif kualitatif analisis diambil dari dokumentasi, sedangkan deskriptif kuantitatif berdasarkan hasil dari observasi terhadap keterampilan proses sains melalui metode eksperimen berbahan alam di PAUD Tashwirul Afkar Gedangan Sidoarjo. Kemudian data di refleksikan serta di analisis, selanjutnya dilakukan tindakan lapangan.

Kriteria keberhasilan tindakan adalah terjadinya kenaikan ketuntasan belajar (setelah tindakan siklus II ketuntasan belajar mencapai sekurang-kurangnya 75\%). Adapun kriteria keberhasilannya adalah sebagai berikut:

Tabel 2. Target Keberhasilan

\begin{tabular}{cccc}
\hline $\begin{array}{c}\text { Taraf } \\
\text { penguasaan } \\
\begin{array}{c}\text { atau } \\
\text { kemampuan } \\
(\%)\end{array}\end{array}$ & Kualifikasi & $\begin{array}{c}\text { Nilai } \\
\text { Angka }\end{array}$ & Keterangan \\
\hline $75 \%-100 \%$ & Sangat Baik & $9-12$ & Berhasil \\
$40 \%-74 \%$ & Kurang & $5-9$ & Tidak Berhasil \\
& & & \\
\hline
\end{tabular}

\section{HASIL PENELITIAN}

Sebelum melakukan tindakan pada siklus I, peneliti melakukan kegiatan pra siklus terlebih dahulu dengan memberikan aktivitas pembelajaran pada anak tanpa menggunakan metode eksperimen, yaitu mengajak anak bereksplorasi menggunakan LKS yang dimiliki oleh anak-anak. Adapun hasil 
keterampilan proses sains pada pra siklus sebagai berikut:

Tabel 3. Rekapitulasi hasil keterampilan proses sains anak pada pra siklus

\begin{tabular}{|c|c|c|c|c|c|}
\hline \multirow{2}{*}{ No. } & \multirow{2}{*}{ Keterampilan proses sains } & \multicolumn{4}{|c|}{$\begin{array}{l}\text { Frekuensi hasil keterampilan } \\
\text { proses sains }\end{array}$} \\
\hline & & 1 & 2 & 3 & 4 \\
\hline 1. & $\begin{array}{l}\text { Anak mampu melakukan } \\
\text { eksplorasi terhadap } \\
\text { berbagai benda }\end{array}$ & 9 & 4 & & \\
\hline 2. & $\begin{array}{l}\text { Anak mampu } \\
\text { mengkonstruksi } \\
\text { pengetahuannya sendiri }\end{array}$ & 9 & 4 & & \\
\hline 3. & $\begin{array}{l}\text { Anak mampu menjawab } \\
\text { pertanyaan apa dan } \\
\text { bagaimana }\end{array}$ & 10 & 3 & & \\
\hline
\end{tabular}

Keterangan:

$1=$ Belum berkembang

$2=$ Mulai berkembang

$3=$ Berkembang sesuai harapan

$4=$ Berkembang sangat baik

Berdasarkan lembar penilaian keterampilan proses sains anak pada pra siklus dapat diketahui bahwa nilai ketuntasan keseluruhan anak kelompok B yaitu mendapat prosentase $33 \%$ hal ini menunjukkan bahwa keterampilan proses sains anak kelompok B masih rendah. Sehingga peneliti beranggapan perlu untuk mengadakan tindakan untuk memperoleh peningkatan dengan menerapkan metode eksperimen, agar anak didik tidak merasa bosan dalam melakukan pembelajaran karena metode ini anak terlibat langsung dalam percobaan-percobaan.

Pada siklus I, peneliti mengajak anak untuk melakukan eksperimen berupa menumbuk kulit manggis, menghaluskan daun pandan dan menghaluskan kunyit.

Pada saat kegiatan pembelajaran menggunakan metode eksperimen berbahan alam yang dilakukan, peneliti melakukan pengamatan keterampilan proses sains anak dengan dibantu oleh guru kelas dan guru pendamping. Adapun hasil keterampilan proses sains anak pada siklus I sebagai berikut:
Tabel 4. Rekapitulasi hasil keterampilan proses sains anak pada Siklus I

\begin{tabular}{|c|c|c|c|c|c|}
\hline \multirow{2}{*}{ No. } & \multirow{2}{*}{ Keterampilan proses sains } & \multicolumn{4}{|c|}{$\begin{array}{c}\text { Frekuensi hasil keterampilan } \\
\text { proses sains }\end{array}$} \\
\hline & & 1 & 2 & 3 & 4 \\
\hline 1. & $\begin{array}{l}\text { Anak mampu melakukan } \\
\text { eksplorasi terhadap } \\
\text { berbagai benda }\end{array}$ & 2 & 7 & 4 & \\
\hline 2. & $\begin{array}{l}\text { Anak mampu } \\
\text { mengkonstruksi } \\
\text { pengetahuannya sendiri }\end{array}$ & 1 & 7 & 5 & \\
\hline 3. & $\begin{array}{l}\text { Anak mampu menjawab } \\
\text { pertanyaan apa dan } \\
\text { bagaimana }\end{array}$ & & 8 & 5 & \\
\hline
\end{tabular}

Keterangan:

$1=$ Belum berkembang

$2=$ Mulai berkembang

$3=$ Berkembang sesuai harapan

$4=$ Berkembang sangat baik

Pada siklus I keterampilan proses sains anak memperoleh nilai ketuntasan 58\%. Hal ini menunjukkan bahwa penerapan metode eksperimen berbahan alam untuk meningkatkan keterampilan proses sains anak kelompok B pada siklus I belum berhasil. Berdasarkan hasil wawancara anak-anak cenderung bingung pada saat menghaluskan kulit manggis, dan anak-anak takut warna kulit manggis terkena baju mereka. Berdasarkan hasil refleksi, maka peneliti memutuskan serta merencanakan untuk melakukan perbaikan tindakan yang dilakukan pada siklus II dengan merubah salah satu bahan dan menambah alat agar percobaan mendapatkan hasil maksimal di siklus II.

Pada siklus II, peneliti melakukan perubahan yaitu, dengan menambahkan celemek dalam kegiatan percobaan agar anak dapat melakukan eksperimen dengan bebas tanpa takut bajunya kotor, dan mengganti bahan daun pandan dengan bahan daun bayam. Dan anak-anak tetap diajak belajar sambil bermain dengan menggunakan metode eksperimen dengan memberikan kesempatan pada anak untuk mencoba dan berkesplorasi terhadap 
bahan-bahan yang sudah disediakan oleh guru. Adapun hasil keterampilan proses sains anak pada siklus II sebagai berikut:

Tabel 5. Rekapitulasi hasil keterampilan proses sains anak pada Siklus II

\begin{tabular}{|c|c|c|c|c|c|}
\hline \multirow{2}{*}{ No. } & \multirow{2}{*}{ Keterampilan proses sains } & \multicolumn{4}{|c|}{$\begin{array}{c}\text { Frekuensi hasil keterampilan } \\
\text { proses sains }\end{array}$} \\
\hline & & 1 & 2 & 3 & 4 \\
\hline 1. & $\begin{array}{l}\text { Anak mampu melakukan } \\
\text { eksplorasi terhadap } \\
\text { berbagai benda }\end{array}$ & & & 4 & 9 \\
\hline 2. & $\begin{array}{l}\text { Anak mampu } \\
\text { mengkonstruksi } \\
\text { pengetahuannya sendiri }\end{array}$ & & 1 & 3 & 9 \\
\hline 3. & $\begin{array}{l}\text { Anak mampu menjawab } \\
\text { pertanyaan apa dan } \\
\text { bagaimana }\end{array}$ & & 1 & 3 & 9 \\
\hline $\begin{array}{l}\mathrm{Ke} \\
1= \\
2= \\
3= \\
4=\end{array}$ & $\begin{array}{l}\text { rangan: } \\
\text { 3elum berkembang } \\
\text { Mulai berkembang } \\
\text { 3erkembang sesuai harapan } \\
\text { 3erkembang sangat baik }\end{array}$ & & & & \\
\hline
\end{tabular}

Hasil keterampilan proses sains pada siklus II didapatkan 11 anak (91\%) yang sudah mencapai ketuntasan dan 2 anak (9\%) masih belum mencapai ketuntasan, dapat dikatakan mengalami peningkatan antara siklus I dan siklus II. Berdasarkan hasil pengamatan dan penilaian yang telah dilakukan, diperoleh hasil bahwa pada kegiatan pembelajaran bermain warna dengan menggunakan bahan alam, situasi pembelajaran yang terjadi pada saat siklus II adalah dengan penambahan celemek, anak lebih leluasa dalam bereksplorasi tanpa takut bajunya kotor. Dan mengganti daun pandan dengan sayur bayam karena tekstur sayur bayam lebih lembut dari pada daun pandan yang berserat. Situasi pembelajaran bermain warna dengan bahan alam yang terjadi pada siklus II adalah anak-anak sudah bisa melakukan sendiri.

\section{PEMBAHASAN}

Berdasarkan hasil rekapitulasi di atas menunjukkan adanya peningkatan yang signifikan. Dari pra siklus, mencapai nilai 33\% dari 13 anak hanya 3 anak yang mampu bereksplorasi terhadap lingkungan, pada siklus I hasil persentase meningkat menjadi 58\% dari 13 anak hanya 5 anak yang dapat bereksplorasi terhadap lingkungan, dan pada siklus II hasil persentase meningkat menjadi 91\% dari 11 anak hampir semua sudah mampu bereksplorasi terhadap lingkungan dan 2 anak yang kurang mampu. Sehingga dapat disimpulkan bahwa pembelajaran dengan menggunakan metode eksperimen dapat meningkatkan keterampilan proses sains anak dalam kelompok B.

Hal ini menunjukkan bahwa pada siklus II upaya penerapan metode eksperimen berbahan alam untuk meningkatkan keterampilan proses sains anak sudah berjalan dengan baik, dan kendala-kendala yang terjadi pada siklus I tidak terjadi lagi pada siklus II. Sehingga keterampilan proses sains anak kelompok B meningkat secara signifikan.

Dengan kata lain pembelajaran dengan metode eksperimen berbahan alam ini dapat meningkatkan keterampilan proses sains anak. Hal ini juga didukung oleh pendapat Sugiharto (2013:81) bahwa metode eksperimen adalah metode pembelajaran yang memberikan kesempatan anak untuk melakukan proses atau percobaan.

Selain itu, peningkatan keterampilan proses sains pada anak melalui metode eksperimen berbahan alam ini terjadi karena adanya pendekatan guru yang dilakukan pada setiap anak, dan memberikan semangat lebih pada anak serta memberikan kesempatan pada anak untuk berkonsentrasi dalam melakukan kegiatan bermain 
warna sehingga hasil yang diharapakan pada peserta didik dapat berkembang sangat baik.

Penerapan metode eksperimen berbahan alam sangat baik untuk menstimulasi kemampuan kognitif, afektif, dan psikomotor. Seperti yang dijelaskan oleh Slamet Suyanto (2015:76-78) dengan metode eksperimen berbahan alam anak dapat menjelaskan tentang proses terjadinya sesuatu dengan menerapkan prinsip learning by experience (belajar dari pengalaman). Sehingga dari percobaan diatas anak mengetahui proses terjadinya sesuatu, anak dapat bereksplorasi terhadap benda hidup maupun benda mati, anak dapat menggunakan panca inderanya untuk mengenal berbagai benda dan peristiwa.

Saat proses pembelajaran anak dapat berinteraksi langsung dengan kegiatan yang diberikan oleh guru dan membuat eksperimeneksperimen terutama dalam bidang sains. Dengan begitu anak dapat memahami proses dari kegiatan yang diberikan, mengerti konsep-konsep sains, dan tentunya mendukung kemampuan kognitif anak dalam keterampilan pembelajaran sains. Berdasarkan hasil pengamatan peneliti bahwa dengan diterapkannya metode eksperimen di PAUD Tashwirul Afkar Gedangan anak-anak mengalami peningkatan dalam bidang kognitif khususnya dalam bidang sains.

\section{SIMPULAN DAN SARAN}

\subsection{Simpulan}

Berdasarkan hasil penelitian yang dilakukan maka dapat disimpulkan bahwa terjadi peningkatan keterampilan proses sains anak setelah dilakukan kegiatan dengan metode eksperimen berbahan alam. Dan penerapan metode eksperimen berbahan alam untuk meningkatkan keterampilan proses sains anak kelompok B dapat dilakukan dengan mengajak anak menghaluskan kulit manggis, menumbuk kunyit, dan menghaluskan daun bayam. Dengan cara yang pertama tahap mengamati seperti membau, melihat bentuk atau bahan yang akan dibuat percobaan, yang kedua tahap mengklasifikasikan atau mengelompokkan dengan cara membandingkan, mencari persamaan, atau mencari perbedaan bentuk dan fungsi bahan, dan yang terakhir tahap menafsirkan dengan cara menarik kesimpulan dan memberi arti dari penerapan percobaan yang telah dilakukan

\subsection{Saran}

Adapun saran yang dapat diberikan setelah dilakukan penelitian ini adalah sebagai berikut:

1. Hendaknya guru lebih menstimulasi atau merangsang keterampilan anak dengan cara yang tepat. Pemberian stimulus seperti bermain langsung dengan alam sangat dianjurkan dalam pembelajaran untuk meningkatkan keterampilan proses sains anak.

2. Dalam menggunakan media dan metode pembelajaran, sebaiknya guru memilih media dan metode yang tepat dan bervariasi setiap harinya agar siswa lebih bersemangat untuk meningkatkan keterampilan pada saat proses pembelajaran berlangsung,

3. Dalam proses pembelajaran hendaknya guru lebih melatih, membimbing, dan memotivasi siswa dalam mengembangkan keterampilan proses sains anak. 


\section{REFERENSI}

Amir, Mohammad Faizal. (2017). Metodologi Penelitian Dasar Bidang Pendidikan. Sidoarjo: UMSIDA Press.

Arikunto, Suharsimi. (2010). Penelitian Tindakan Kelas Untuk Kepala Sekolah dan Pengawas. Yogyakarta: Aditya Medika.

Kusumah, Wijaya. (2017). Mengenal Penelitian Tindakan Kelas. Jakarta: PT.Permata Puri Media.

Nugraha, Ali. (2015). Pengembangan Pembelajaran Sains Pada Anak Usia Dini. Jakarta: Departemen Pendidikan Nasional.
Samatowa, Usman. (2018). Metodologi Pembelajaran Sains untuk PAUD. Tangerang: Tira Smart.

Sugiharto dkk. (2013). Psikologi Pendidikan. Yogyakarta:UNY.

Suyanto, Slamet. (2014). Strategi Pendidikan Anak. Yogyakarta: Hikayat.

Widiyanti. (2016). Skripsi. Meningkatkan Keterampilan Proses Sains Melalui Metode Eksperimen Pada Anak Kelompok B TK KKLKMD. Universitas Negeri Yogyakarta. 